\title{
Implementation Tools of Central Budget in the Context of Gender Justice
}

\author{
Balasaheb Annasaheb Bhagat ${ }^{* 1}$, Prashanth S. Salave ${ }^{2}$ \\ ${ }^{1}$ Research Scholar, Shri jagdish prasad jhabarmal tibrewala university, vidyanagari, Jhunjhunu, rajasthan - \\ 333001. \\ ${ }^{2}$ Department of Commerce, Shri jagdish prasad jhabarmal tibrewala university, vidyanagari, Jhunjhunu, \\ rajasthan -333001 .
}

\begin{abstract}
Wome are neglected half in Indian society and women is always given secondary treatment. Hence, gender justice is a significant and challenging research area in the new world. Gender justice is based on social and economic environment credited through infrastructure economic provisions as well as opportunities give to women for development. Gendr justice is aimed to empower women not only throw microfinance and self help groups but also through the development of new schemes for women's all-round development in the various fields of national life, such as agriculture, industries and education. Analyzing programmes, strategies, interventions and policy initiatives from the perspective of their impact on status of women as reflected in important macro indicators like literacy, maternal mortality rate (MMR), participation in work force, e.g. analysis of substance and content of various interventions directed at health of women and correlate the same with indicators like MMR to establish need for corrective action in formulation of scheme/ approach. Gender Budgeting is a strategy for ensuring Gender Sensitive Resource Allocation and a tool for engendering macro economic policy, not a separate budget for women. In context of Gender Diagnosis a access to Resources POSITIVES Female life expectancy doubled from 31.7 years in 1951 to 60.9 years in 1994. Female life expectancy at birth surpassed that of man (59.7 years). Declining trends in IMR and CMR. Increase in female literacy rate Increase in female gross enrolment ratio. NEGATIVES Adverse sex ratio female IMR > male IMR female CMR> male CMR MMR as high as 540 per one lakh live births (NFHS-2) Around half of Indian women are illiterate (54.28\% in Census 2001). Female enrolment less than half, lagging much from $100 \%$ target.

Keywords: Central budget, Gender justice, religious communities, Budgets garner resources.
\end{abstract}

\section{Introduction}

All over the world, both women and men play important roles in society. However, their positions in the economy and the remuneration they earn are different. Traditionally, much of the work that women do has not been recognised as part of economic activity. In recent years, however, time use studies have helped to highlight the definite but different contributions of women and men to the whole economy. The figure below shows the structure of the economy when work done in households is included.

Rajesh $(2014)^{1}$ reported on Gender Justice in Advertisements: Study of Indian Commercials. Television commercials have more to convey than any other media of communication in the present day scenario. Very short, straight yet creative messages are conveyed to the target audience with a messenger. Vijaya Mahajan $(2012)^{2}$ reported on Women Empowerment and Social Justice: A Socialist Feminist Social Work Approach. Down the ages women are considered weak; do not have abilities, capabilities to take care of themselves, so the male member of the family, society should protect them. In the society, the women's, social economical participation is limited or restricted due to lack of and access to opportunities. Such situations make them fall pray to exploitations. Carr M, ChenM, jhabwala R. $(1998)^{3}$ have edited a book titled as speaking out, women's economic empowerment in South Asia. This book is a significant landmark in gender studies. The book has included number of articles in south asian context. This book has helped a great deal to understand the problems. For the present study also this book has prove useful.

\section{Gender Budget Analysis Tools}

\section{Methodology}

Why Budget Analysis? Budgets are crucial: determine how governments mobilize and allocate public resources shape policies, set priorities an economic process: deals with allocation and mobilization of resources articulates the macro economic policies of the state political instrument: voted on and mediates competition between people and interests instrument for fulfilling obligations of the state in respecting, protecting,promoting human rights. The Concept and its Tools Three levels: Inputs : financial appropriations vs.. need: appropriations vs. actual expenditure: sector wise shares of expenditure and real per capita: revenue side Activities supported by appropriations: public services, delivery costs, income transfers Outcomes expected from appropriations vs. 
actual outcomes including unintended ones: whether the money is being used in a manner that effectively achieves planned outcomes and where it is failing ${ }^{4}$.

Tool 1: Gender-Aware Policy Appraisal-Linking Budgets to Policies 3 steps: 1. examine position of women and men, boys and girls in each area of economic and social life addressed by the budget, taking into account age, ethnic group,location and class; 2 . examine whether government policy adequately addresses inequalities which have been identified; 3. examine whether resources are being allocated in ways that are likely to reduce inequalities. Step 3: Flow Chart Planned outcomes e.g. healthy, educated, well nourished people An efficient economy A well governed country Planned activities Public services Public income transfer Legislation Planned inputs Financial appropriations Planned capacity Staff Equipment etc Unexpected effects Unintended consequences + and - Expected Impacts Human development Empowerment of women.

Tools 2: Beneficiary Assessments Techniques include: Opinion polls, attitude surveys, focus groups, interviews, role play

Tool 3: Public Expenditure Incidence Analysis Gives a sense of how gender-inclusive expenditures actually are by comparing the distribution of public spending among women and men, girls and boys. Three steps: 1 . Estimate unit cost of providing a service. e.g., 1 primary school place for 1 year 2. Estimate use of service by men and women, boys and girls e.g., number of primary school places occupied by girls and boys 3. Calculate amount spent per year on girls and boys.

Tool 4: Revenue Incidence Analysis Shows proportion of income paid in taxes and user charges by different categories of individuals or households.

Tool 5: Sex-Disaggregated Analysis of the Impact of the Budget on Time Use Similar to tool 1- but focuses in particular on the outcome for the amount of unpaid care work done by women and men Whenever expenditure cuts are proposed, the question should be asked: Is this likely to increase the time that men and women spend on unpaid care work?

Tool 6: Gender-Aware Medium-Term Economic Policy Framework Incorporation of gender variables into the models used for medium-term public expenditure planning are based. For example, inclusion of: sexdisaggregated variables in the labour market component new variables to represent the unpaid care economy

Tool 7: Gender-aware Budget Statement Any government can issue a gender-aware budget statement utilizing one or more of the above tools to analyze its programmes and budgets. Some key indicators for a gender-aware budget statement. -share of expenditure targeted to gender equality -women's participation in the public-sector employment relative to men. -the share of prioritized expenditures towards women.

\section{Framework to measure gender equality}

- Gender equality in the capabilities domain, such as in health, education and nutrition and other basic human abilities.

- Gender equality in access to resources and opportunity domain refers to equality in opportunity to use or apply basic capabilities through control over economic assets (such as land and property) and resources (such as income, credit and employment) as well as participation in decision-making.

- Gender equality in the security domain is defined as reduced vulnerability to violence and conflict.

All the three domains are inter-dependent and enhance women's agency, which is the capacity to shape decisions that affect one's life at the household, community, national and global levels.

\section{Strengthening governance through gender-responsive budgeting}

By way of strengthening economic and financial governance through gender-responsive budgeting, the Government of Belgium hosted a High Level conference in Brussels on 16-17 October 2001 - sponsored by the Organisation for Economic Co-operation and Development

(OECD) and supported by the Nordic Council of Ministers, the Government of Italy, UNIFEM, the Commonwealth Secretariat, and the International Development Research Centre-Canada (IDRC) ${ }^{5}$. The goal was to mobilise political and financial support to strengthen the capacity of governments and civil society organisations to carry out initiatives and to support the global vision of gender-responsive budget initiatives in all countries by 2015 . The conference urged governments, international and intergovernmental organisations, multilateral institutions and non-governmental organisations to: 
$>$ Encourage the examination of budget processes and objectives to ensure that women's and men's needs and priorities are considered equally;

$>$ Encourage women to participate in this examination, including as elected representatives and members of women's organisations; and involve the research community, development banks and civil society;

$>$ Encourage the incorporation of gender analysis in the preparation, implementation, audit and evaluation of government budgets at all levels; and show commitment to transparency and accountability by encouraging the application of gender analysis in government budget reports, including by setting out and reporting on the impact of past budgets and the expected impact of the proposed budget on gender equality objectives;

$>$ Recognise the use of gender-responsive budget initiatives as a tool to enhance the way civil society preferences and needs are incorporated into the budget, to improve transparency and equality, reduce poverty and achieve good economic and financial governance;

$>$ Encourage and support gender responsive budget initiatives worldwide and call on the Nordic Council of Ministers, the OECD, and UNIFEM in cooperation with the Commonwealth Secretariat and the International Development Research Centre -Canada and other relevantbodies, to continue to provide research, technical or methodological support for these initiatives;

$>$ Promote the catalytic and supportive role of international and development cooperation, including through increasing support for gender budget initiatives.

\section{How to perform a gender analysis of budgets}

Several tools have been developed for use in gender analysis of expenditures and revenues. A commonly used tool is the Gender-Aware Budget Statement, which can be applied to the whole budget or to a number of sectors. Expenditures and revenues are analysed, using various tools, for their likely impacts on different groups of women and men, girls and boys ${ }^{6}$.

\section{Step 1: Situation gender analysis of a sector}

This analysis begins with studying key documents and data on gender issues in the country and identifying their underlying causes and effects, both immediate and long-term. Very often, parliamentarians and civil society organisations have a fair idea about the social and economic situation of women and men, girls and boys in their constituencies. Data can be found in the line ministries, statistical departments and international reports.

\section{Step 2: Gender analysis of sector policy}

In the second stage, sector policy and programme documents are examined to see whether they address the gender issues previously identified. Does the policy reduce gender inequalities, leave them as they are or increase them?

\section{Step 3: Gender analysis of budget allocations}

The third stage analyses the extent to which any policy commitments to addressing gender concerns are matched by allocations from the budget. Does the government do what it says it is going to do? An assessment is also made of whether the allocations address the gender issues identified in step one.

\section{Framework for gender analysis of expenditures}

Rhonda Sharp's framework is often used to break down expenditures into three categories:

1. Gender-specific allocations are allocations specifically targeting women and girls or men and boys. For example, school bursaries for girls or domestic violence counselling for men. Many governments have allocated special funds for women's programmes. It is important to analyse their impact on women's lives and ensure that such programmes give value for money. However, experience shows that gender-specific allocations are very small compared to the rest of the budget, usually less than 1 per cent.

2. Mainstream allocations need to be examined for their gendered impacts. Most expenditures fall in this category and the real challenge of gender analysis of budgets is to examine whether such allocations address the needs of women and men, girls and boys of different social and economic backgrounds equitably.

3. Equal opportunity employment allocations are allocations intended to promote gender equality in the public service. For example, day-care facilities for employees' children, paid parental leave, or special training for women middle-level managers. Particular attention is paid to the decision making levels because public service delivery systems make important decisions which impact on the lives of poor women and men. If they are not gender balanced, their decisions are likely to be gender-insensitive. 


\section{Challenges and limiting factors in gender budgeting}

Various challenges remain in implementing gender budgeting and accepting the analysis generated by these processes, including:

Collection of sex-disaggregated data: In most countries there is some sex-disaggregated data within and outside government which can be useful. However, there is a need to generate more information in order to shed more light on the differences between women and men, girls and boys, particularly in access to resources, opportunities and security. Without accurate and relevant data, it is not possible to integrate a gender perspective in the budget process. For legislators, information to enable a gender analysis of the budget should be timely and brief enough to be utilised during the period of budget debate.

Assessing priority areas: There may be budgetary constraints or 'trade-offs' which make it difficult to prioritise outcomes suggested by gender-responsive budgeting. A gender disaggregated beneficiary incidence analysis may identify the different needs and interests of women and men with respect to a particular service but how does that information translate into priority changes in policy and expenditure patterns? How, for example, does an analyst compare differential spending on healthcare for men and women, since they have different healthcare needs and issues? There is a need to develop appropriate frameworks to assist in determining priority gender issues within and across sectors in the context of the whole budget. This is particularly important where country-wide poverty reduction strategies are being implemented.

From analysis to changes in policy and budgets: Currently, most of the gender budgeting initiatives worldwide are at the stage of analysis and there is limited evidence connecting analysis with policy and budget changes. This is not surprising given the rigidity of government decision-making processes and the tendency of public officials to avoid experimentation such as that involved in gender-sensitive budgeting. A few initiatives, such as that of the Tanzania Gender Networking programme have moved beyond analysis to mainstreaming gender into the budget (Rusimbi et al 2000). There is no prescribed formula or recipe for achieving a genderresponsive budget.

Limitations on legislative intervention: Legislatures, in partnership with gender experts and civil society groups, have sometimes played an important advocacy role, for instance in South Africa, Uganda and Scotland. However, there are limits to parliamentary interventions. The role of legislatures in the budget process is often confined to budgetary approval and oversight, while budget formulation and execution are more commonly functions of the executive. To integrate a gender perspective in a budget requires gender mainstreaming of policies and programmes behind the budget. An active and gender-aware legislature can use the enactment stage to question budget priorities and call for allocations to promote equality.

Institutionalising gender budgeting tools: Gender budgeting requires political will, adequate resources and capacity, and a high level of budget 'literacy' amongst civil society partners and within women's policy-making machinery (women's bureaucracies and parliamentarians). Gender-responsive budgeting is a political tool to call for accountability on issues of gender equality. It is a powerful factor for change and its success depends on whether political will can be generated within government to support a process of transforming the traditional budget-making and policy processes by removing long-standing, in-built biases which disadvantage women and girls.

\section{Women.s Component Plan and Gender Budgeting:}

The planning Commission of India has always focused on women.s issues as per the perceptions of their members on women.s status within the economy. The First Five Year Plan (1951-1956) set up Central Social Welfare Board in 1953 to promote welfare work through voluntary organisations, charitable trusts and philanthropic agencies. The Second Five Year Plan (1956- 1960) supported development of Mahila mandals for grass roots work among women. The Third, Fourth and Interim Plans (1961-74) made provision for women.s education, pre-natal and child health services, supplementary feeding for children, nursing and expectant mothers. The Fifth Plan (1974-1978) marked a major shift in the approach towards women, from welfare to development. The Sixth Plan (1980-85) accepted women.s development as a separate economic agenda. The Multidisciplinary approach with three- pronged thrust on health, education and employment ${ }^{7}$.

Measurement of development has to go beyond achievement of GDP growth to indicators of distributive justice and their monitoring. Women headed households have to be specifically targeted, identifying added disadvantages in the rural and urban locations with reference to different parameters of deprivation. Formulation 
of Gender Development Indicators to measure Human Development and their use as a tool for monitoring development needs to be hastened ${ }^{22}$.

National Human Development Report (HDR), 2001:

The first HDR prepared by the Planning Commission of India reveals that gender disparity across the states has declined. The report has given Gender Equity Index (GEI) in which Bihar has the most abysmal record of 0.49.GEI of U.P. and Assam is between 0.5- 0.59. Maharashtra, Orissa, Rajasthan, West Bengal figure in the GEI bracket 0.6- 0.74. The group in the topmost bracket i.e. $0.75+$ is composed of the North Eastern states except Assam, Southern states and Himachal Pradesh. The HDR has not seriously taken into account, the declining sex ratio, especially the juvenile sex ratio (0-9 years) while estimating various development indices. The report has used 8 indicators to map the human development of states. It has provided diagrammatic representation of human development in the form of development radars comprising of 8 indicators namelyincidence of poverty, per capita consumption expenditure, life expectancy at age one, infant mortality rates, intensity of formal education, literacy rates, access to safe drinking water, proportion of households with pucca houses. The central thesis of HDR has been economic prosperity in terms of high per capita income does not necessarily lead to overall human development. Declining sex ratio in the prosperous states like Punjab, Haryana, Gujarat and Maharashtra prove the point. There is a need to focus more on the impact of budgetary allocations on women.s well-being and women.s development ${ }^{8}$.

\section{A State Profile of Maharashtra:}

Human Development Report, 2002 Maharashtra published on 4-6-2002 has lamented the skewed development of Maharashtra that has a bearing on its relatively lower place on the Human Development Index despite its per capita state domestic product, which is higher by $40 \%$ of the national average. ${ }^{9}$ HDR, 2002 recommends empowerment of women by better targeting of compulsory elementary education and growth of medicare in the public domain by public spending. The report states that focused attention is needed to empower women by.

1. Strict enforcement of the legally marriageable age which would, in turn improve their health, give them the time to complete secondary education, correct female-male ratio, delay childbearing tasks till they are ready.

2. Punishing female foeticide

3. Avoiding the system of male proxies for elected women and restore true power to women.

4. Targeting improvement of women.s health to reduce anemia and make possible for children born being healthier. (Ratnakar Mahajan, 2002)

HDR Maharashtra, 2002 has also recommended enhancing nutritional status of women by ensuring food-security and netting more and more eligible women and children under the ICDS.

\section{Maharashtra Policy for Women:}

The state government of Maharashtra took major initiative to bring gender concerns on the social and political agenda of the state by preparing a policy document, POLICY FOR WOMEN IN MAHARASHTRA ${ }^{\mathbf{1 0}}$. As the document declares, the policy is .an attempt to identify immediate steps that the state can take to improve the position of women ${ }^{24}$. Important features of the policy are:

- Statutory provision for reserving $10 \%$ of all income and land at the gram panchayat level under the control of women.s committee.

- Government allotments and primary memberships of societies to be made in the joint names of husband and wife.

- Amendments in the Hindu Law of Inheritance (1956) for ensuring equal share of the movable and immovable property of the husband.

- Reservation of $30 \%$ of government jobs for women.

- Women would constitute $25 \%$ of the police force in the state of Maharashtra. The state should take steps to re-orient and retain police force and set up women headed police stations in metropolitan cities to safeguard women against violence and atrocities.

\section{Maharashtra Population Policy Statement: Vision 2010-A Gender Analysis:}

As budgetary provision for population stabilization has increased, when the overall budget for social sector dealing with developmental issues has declined, I find it necessary to provide

detailed analysis of the Vision 2010. This policy paper is a cautiously written article that avoids all controversial issues related to politically volatile subject such as population policy. This bland and toothless piece of paper 
provides unrealistic generalisations churned out by some ad-agency or a market research manager. It is not written with perspective of guaranteeing reproductive rights of women.

In Maharashtra, the population policy has been the most over-researched area of intellectual activity since last 3 decades in terms of KAP studies, surveys, qualitative analysis and genderanalysis. Collective wisdom arrived at as a result of the field- based studies and action research projects have not been reflected in the document. Some of the missing aspects in the document are as follows:

\section{Health Infrastructure:}

In 1991, there was a shortfall of 808 sub-centres, 61 primary health centres and 139 community health centres in the state. For an effective implementation of the population programme, there is a need to solve this problem on a top priority basis. The state Government revenue expenditure on health in Rs. Per capita is steadily increasing over the last 4 decades. But, in the recent years, it has been less as compared to the health budgets of Jammu and Kashmir, Kerala, Punjab, Karnataka, Tamilnadu and Rajasthan. In Maharashtra, only 13\% of women in public hospitals and $18 \%$ of women in private health institutions are attended to by doctors and another $20 \%$ are handled by traditional birth attendants when they deliver a child. $29 \%$ of pregnant women in the state are not getting Tetanus toxide injection as per the study of International Institute of Population Studies, Deonar, Bombay, 1995. Distribution and marketing of sanitary pads at differential rates should be organised by the public and private sector keeping into consideration specific context of the beneficiaries ${ }^{25}$.

\section{Child Marriage:}

Percentage of girls (below 18) who got married in the rural areas of Maharashtra is as high as 29 and it is $11 \%$ in the urban areas. Nearly 1/4th $(24.6 \%)$ of girls are victims of child-marriage and even more are victims of teen-age-pregnancy (within and outside marriage). The policy needs to spell out a modus operandi to deal with these issues. In the absence of mandatory power and protection from the state, ANMs, gram sevikas, social workers, anganwadi workers and their helpers and women.s rights activists get victimised and witchhunted ${ }^{11}$.

Private sector is increasingly playing a crucial role in implementing population policy. Its prominent role is most visible in areas such as abortion clinics, hospitals offering new reproductive technologies for preconception and ante- natal sex-determination tests, preimplantational genetic diagnosis (PGD), infertility treatments, artificial insemination. Still \% share of MTP (medical termination of pregnancy is only 15.9 among all abortions (legal and illegal) conducted in the state. On an average, one legal centre covers 21079 female populations in Maharashtra. Union territories (Goa, Mizoram, Manipur), tourist centre (Goa) and Delhi have better profile than Maharashtra in terms of safe abortion facility as a back-up service.

\section{Sex Ratio (Number of women per 1000 men) in Maharashtra:}

In the state, there are 922 women per 1000 men and Greater Bombay, there are 774 women per 1000 men, as per the Census of India, 2001. In the age groups of 0-4, 5-14, 15-29, 30-44, 45-49, there are more men than women in the state. Affirmative action to safeguard chances of survival of girl infants, girl-child and young women should be spelt out categorically. Only elderly women are safe as they enjoy honorary men. status but they are also vociferous supporters of sex-determination tests for female foeticide.

\section{Quality of Life of Below Poverty Line population:}

Survival struggles connected with collection of fuel, fodder and water take heavy toll of rural and tribal women in general and pregnant and lactating women in particular. Public health measures to provide safe environment and to reduce women.s drudgery should be taken up on a war footing. Separate toilets (Indian style) for women in the community and public places must be constructed for working women to avoid kidney problems and ensure menstrual hygiene among working women and women commuters. Management of anaemia in pregnancy and low birth-weight babies is a major problem among the below poverty line population. The communities uncovered by ICDS centres are unable to meet nutritional requirements of this category of population. There is a scope for more ICDS centres in the state.

\section{Violence against women and repeated/ forced pregnancy:}

So far the work regarding violence against women has been responsibility of the voluntary organisations. Bombay and Pune Municipal Corporations have started project to provide support services to women victims of domestic violence. Similar efforts are needed in all municipal and government hospitals of the state. Staff Training programmes to deal with increasing violence against women should be started as early as possible. Domestic violence as a result of differences regarding birth control practices, number of children, birth of a girl child-should be treated as a serious social problem and respect should be given to bodily integrity 
of women. Pregnant rape victim within or outside marriage should have a final say regarding continuation or termination of her pregnancy.

\section{Predicaments of women employees involved in implementation of population policy:}

At present, in Maharashtra, trained dais and village health guides cover average population of 793 and 1153 respectively. (Sarala Gopalan and Mira Shiva, 2000). These women are powerless unless they get protection from women elected in Panchayats. Population education and training based on scientific and medically up-to-date course content should be made mandatory for elected representatives- 100182 in Gram Panchayats, 1174 in Panchayat Sabhas and 587 in Zilla Parishads. Their chairpersons- 9203 of Gram Panchayats, 106 of Panchayat Sabhas and 10 of Zilla Parishads should be trained in democratic handling of the policy so that their personal examples become main motivator for efficient handling of the population policy in a congenial and secure environment. (Rohini Gawankar and Usha Thakkar, 2001).

\section{Female Burden of Gynaecological morbidity:}

Clinical study of women in Gadchiroli, (Dr, Dileep Mavalankar, Dr. Rani and Dr. Abhay Bang, 1998) revealed the nature of clinically diagnosed gynaecological morbidity as follows: $62 \%$ of women had vaginitis disorder, $19 \%$ has cervitis, $46 \%$ had cervical erosion, $24 \%$ had pelvic inflammatory disease and $6.76 \%$ had primary and 2dary sterility. Studies of Parinche by FRCH, Nasik, Pune and Bombay studies of CEHAT and Malchiras studies of MASUM have also revealed serious nature of gynaecological morbidity among urban and rural women in Maharashtra that are related to nature of women.s work and public utility services. Occupation related gynaecological problems such as abortions, premature deaths and still-births, high rate of neo-natal, infant and maternal mortality, pelvic inflammatory disorders leading to chronic backpain have been documented in the Sramshakti Report. (Manisha Gupte and Veena Shatrughna,1988). The population policy should address these issues keeping in mind reproductive rights of women. (Reproductive Health, 1998).

Population Education programmes begin and end with a presumption that heterosexual and penetrative sexual activity is a be all and end all of human existence and within this context women.s reproductive functions need to be regulated to establish small family norm. This fascist approach needs to be challenged keeping in mind diverse family-situations. female headed households (popularly known as parityaktas in Maharashtra) managed by widows, deserted women, divorced women, unmarried women, single man and single women raising adopted child/children, lesbian and gay couples with or without their biological or adopted child/children. Maharashtra should take lead in legitimising these plural life situations. Public should be informed about the clinical and procedural aspects of all terminal and non-terminal methods of birth control practices- pills, jelly, diaphragm, condoms with spermicides, anti-pregnancy vaccine, implants, copper-t, ring, vasectomy, tubectomy and recanalisation operations. Informed consent means that the client accepts the method after adequate knowledge of the contraindications ${ }^{\mathbf{1 2}}$.

In the context of massive labour migration and erosion of traditional leisure-time activities among displaced population, sexual activity (within and outside marriage) becomes major time-pass. Revival of traditional festivals, educational melas, science jatras, collective community level activities along with increasing numbers of libraries, song groups, public gardens, sports complexes, art galleries, museum and craft melas, speak-out centres which promote safe human bonding based on mutual respect, care and concern can provide far more superior alternatives than bureaucratically administered contraceptive devices.

\section{Union Budget:}

We have to examine budgetary provision for women during 2001-2002 and 2002-2003 within The matrices provided by the above mentioned policy documents. Women's status and women's bargaining power in the economy have a major bearing in the budgetary policy. Yearly analysis of the budget from the point of view of women is a must to enhance women's economic interest and socio-political standing in the economy. Analysis of budget from gender perspective makes us understand what are the nature, character and content of Women.s share of development cake

\section{India budget: Women let down again}

\section{Results And Discussion}

A look at the Union Budget of India this fiscal year through the gender lens reflects its gross inadequacies on most fronts. The government has done nothing to change its shameful track record on gender budgeting 


\section{Budget for women in difficult circumstances}

The financial allocation of Rs. 200 crore for the 'most vulnerable' groups including single women and widows is an eye wash. Such a paltry amount cannot support schemes like Swadhar, working women's hostels, one-stop crisis centres, a national helpline and the effective implementation of the Prevention of Domestic Violence Act and the recently passed Sexual Harassment at Work Place Act.

\section{Multi-sectoral Programme for reducing maternal and child malnutrition.}

This programme announced last year is to be implemented in 100 districts during 2013-14. It has been allocated Rs. 300 crores to scale up to cover 200 districts the year after. This is a grossly inadequate fund allocation which seeks to address $40 \%$ of children and 55\% women in India who are malnourished.

\section{Integrated Child Development Scheme (ICDS)}

The ICDS gets Rs. 17,700 crore for this fiscal year. In response to galloping inflation, the amount is quite inadequate. A successful implementation of ICDS requires nearly Rs. 3 lakh crore over the 12th plan period as per an estimate made by nutrition experts while allocation has been for Rs. 1.23 lakh crore. Besides this, financial provisions for social security and additional remuneration for Anganwadi Workers and ASHAs, the principal carriers of the flagship schemes have not been made.

\section{Anti poverty programmes and National Health Mission}

The budget has enhanced the allocation for anti-poverty programmes such as Mahatma Gandhi National Rural Employment Guarantee Scheme (Rs. 33000 crores) and the flagship centrally sponsored scheme for public health-National Health Mission (Rs. 21239) whose principal beneficiaries are women as they are the poorest of the poor. The allocation for women specific schemes for economics services, welfare services and social defense have been increased up to 8500 crores.

\section{Public sector bank for women}

The budget has also announced an allocation of Rs. 1000 for an all-women public sector bank in which both the management and clients are expected to be women. The state owned Women's Bank will work for financial inclusion and empowerment of self help groups, women entrepreneurs, self employed women and support livelihood needs of women. At last, the state finds women bankable!

\section{Nirbhaya Fund for empowerment of women}

The sustained agitation by Indian youth and women after the gang rape of the 23-year-old (who was named by media as Nirbhaya) physiotherapist in a moving bus on 16th Dec. 2013 shook the whole world. To appease the angry youth, the budget has announced Rs. 1000 crore as seed money for a 'Nirbhaya Fund'. However, there is no clear mandate for this Fund - that it will be used for rehabilitation of survivors of sexual violence and acid attacks.

\section{Inadequate funds for education}

There is no increase in allocation to education as suggested by the Kothari Commission in 1966. The focus on Sarva Shiksha Abhiyan is not enough. Aspirations for higher education have enhanced exponentially among Indian Youth. Government aided higher education and vocationalisation of education is the need of the hour. The Union Budget 2013-14, has failed in its duty towards the masses by leaving higher education to the private sector.

\section{No fund for housing for women}

In spite of repeated demands from the women's movement for over 30 years, specific allocations for safe houses and shelters for women who face domestic violence, incest, and for homeless women has not been made. Girls and women facing incest are forced to stay in the same house as their molester for want of a safe shelter.

\section{Homeless women remain ever-vulnerable to violence on the streets.}

To win over middle and upper class women, the budget has offered an incentive of raising the duty free baggage limit for jewellery for women passengers to Rs 100,000, subject to some conditions. From 2004 to 2013, 56 ministries have set up Gender Budget cells. But to make their fiscal policy gender responsive has been an uphill task. Galloping inflation has affected the toiling poor women of India adversely whose real wages have declined sharply. Due to the withdrawal of the state from the social sector, women's work burden in the unpaid care economy (cooking, cleaning, nursing, collecting fuel, fodder, water, etc) has increased many-fold. The subordinate status of women manifests in declining child sex ratio i.e. 'missing girls phenomenon', deteriorating 
reproductive and child health, feminization of poverty, increased violence against women, enhanced mortality and morbidity among girls and women and deplorable condition of elderly women ${ }^{\mathbf{1 3}}$.

\section{Women and Child Development (WCD)}

The Women and Child Development Division handles all the work relating to - i) Empowerment of Women; and ii) Development of Children in close co-ordination with the nodal Department of Women and Child Development. The primary functions of the Division, inter-alia, include the following: Over all Policy Guidance / Advice to both Governmental (central and state levels) and Non-Governmental Organizations in the field of Women and Child Development. Work relating to Five Year and Annual Plans

\section{Central Sector}

$>$ Setting up of Working Groups at the Ministerial level and co-ordination with the nodal Department,

$>$ Setting up of Steering Committees in the Planning Commission and its related work viz. Organizing meetings;

$>$ Preparation of background /agenda / minutes of the meetings;

$>$ Preparation of Steering Committee Reports;

$>$ Approach paper and the relevant Chapter for inclusion in the Plan Document.

$>$ Examination of Plan Proposals (Five Year and Annual Plans) and preliminary discussions with the Ministry;

$>$ Coordination with the Department with regard to Central Working Groups; and Recommendation of Outlays;

$>$ Budget / Re-appropriation matters.

\section{State Sector}

$>$ Examination of Plan Proposals; Organizing State Sectoral Working Group Discussions to review the implementation of both Policies and Programmes including the physical and financial targets /achievements;

$>$ Recommendation of Sectoral Outlays;

$>$ Mid-Term Appraisal

$>$ Preview of the progress of implementation of Policies and Programmes,

$>$ Review of achievements in relation to the targets (both physical and financial),

$>$ Suggestions for Mid-Term corrections.

$>$ Examination and preparation of Briefs along with the Comments in respect of - i) Cabinet Notes; ii) EFC Memos; iii) SFC Memos with regard to Schemes relating to Women and Children, besides attending EFC/SFC Meetings.

$>$ Advisory role with regard to the Subordinate/Attached Organisations viz, National Commission for

$>$ Women (NCW), New Delhi; Central Social Welfare Board (CSWB), New Delhi; National Institute for

$>$ Public Co-operation and Child Development (NIPCCD), New Delhi; Rashtrya Mahila Kosh (RMK), New Delhi.

$>$ Represening Planning Commission in the meetings of - Parliamentry Committees; Inter-Minstrial /

$>$ Departmental Co ordination Committees; Expert Committees; Task Force on the Subject; Project

$>$ Sanctioning Committees; Special Committees: Study Teams; etc. set up from time to time by the

$>$ Department; Governing Board and General Body Meetings of the Subordinate Organizations.

$>$ All Parliamentary matters viz. answaring Questions, supply of material within and outside the Planning Commission.

$>$ Co-ordination with - i) women and child - related Ministies/ Departments; ii) Subject

$>$ Divisions within the Planning Commission; and iii) UN and other International Agencies.

$>$ Special Initiatives like - i) Preparation of Policy Oriented Papers; ii) Bringing out Statistical

$>$ Profiles and other Publications; iii) Developing Information / Data-Base.

$>$ Any other work including preparation of Speeches and writing Articles relating to Women and Child

National constitutions usually state that all citizens are equal under the law and prohibit discrimination against women. By signing international human rights agreements such asthe Universal Declaration of Human Rights (UDHR), the UN Covenant on Economic, Social and Cultural Rights (CESCR), the UN Convention on the Elimination of All forms of Discrimination against Women (CEDAW), and the Beijing Platform For Action (BPFA), governments have committed to working progressively towards equality and equity between women and men, girls and boys. At the UN Millennium Summit in 2000, governments of the world endorsed the Millennium Development Goals (MDG) to be achieved by the year 2015. Gender equality and women's empowerment is the third MDG. It is also recognised that it will be difficult to achieve the other MDGs without 
the attainment of gender equality. Governments therefore have a moral and legal obligation to achieve this goal $^{14}$.

\section{Relating Outlays to Outcomes}

While an assessment of the quantum of allocations helps us understand the government's priorities for different sectors, it is equally important to examine whether such allocations translate into better outcomes for its intended beneficiaries. If we look at the outcome indicators available for different areas, the situation does not appear to be very encouraging (refer to table 2). Some significant instances are: Although there has been significant improvement in the enrolment rate of girls over the years, the dropout rates for girls particularly from the marginalised communities continue to be alarmingly high. Similar concerns emerge in the area of maternal health. Although the maternal mortality rate has declined, the overall figure masks the huge interstate variations. High percentage of maternal deaths continues to occur in the states of Uttar Pradesh, Uttaranchal and Assam. If we look at women's political participation, the participation of women in the national legislature remains very low. Currently the percentage of women in the Parliament is only $9.7 \%$ which is far less than that of Pakistan, Afghanistan and Rwanda ${ }^{15}$.

One of the major reasons for unsatisfactory outcomes is underutilisation of funds. This has been a key finding of study by Centre for Budget and Governance Accountability (unpublished) on maternal health in two districts of UP and Chhattisgarh. The study clearly establishes the fact that better outlays do not necessarily translate into better outcomes. Two broad concerns can be identified: (a) pattern of spending and (b) quality of spending.

Table 1: Goals, Outcome Indicators and outcome

\begin{tabular}{|l|l|l|}
\hline \multicolumn{1}{|c|}{ Goals } & \multicolumn{1}{|c|}{ Outcome Indicators } & \multicolumn{1}{c|}{ Outcome } \\
\hline Education & Dropout Rate of SC Girls (for Class I-X) & $73.42 \% 15$ \\
& Dropout Rate of ST Girls (for Class I-X) & \\
& & $77.49 \%$ \\
\hline Maternal Health & Maternal Mortality\# & 301 per $1,00,000$ live births \\
\hline Political Participation & Women in National Legislature & $9.7 \%$ \\
\hline
\end{tabular}

Source: MHRD, GoI, SRS 2001-2003

Data collected from the two districts indicate that maternal health grants under plan schemes are crowded towards the latter part of the fiscal year due to delays in clearance of funds and slow implementation at the district and block levels. Fund release and spending is also skewed across critical components within schemes or at the district, block and panchayat levels, since there are no comprehensive guidelines for them under the NRHM umbrella. In Chattisgarh, there were extremely low levels of fund utilization in areas like mobile medical units, selection/training of ASHA/mitanin (community health volunteers) and staff, programme management and upgrading of district hospitals while family planning activities, the polio eradication campaign and JSY saw high utilization between 2006 and 2008. UP meanwhile lacks a proper State Programme Management Unit for monitoring State or Central Schemes. A similar pattern of underutilisation mars the implementation of many of the flagship programmes of the government.

\section{Assessment of Some Flagship Schemes of the Union Government from a Gender Lens}

Focusing on three issues, namely maternal health, opportunities for employment (including working conditions) and education, evidently the focus of the MDGs as far as woman are concerned, let us look at a few flagship schemes to assess whether outlays translate into better outcomes for women. With regard to education of the girl child, the total outlay by the Union government in 2010- 11 is Rs. 15,057 crore. Taking the projected population of girl children in the 5-18 years age group in 2011, i.e. 15.7 crore, an indicative estimate of the per capita expenditure on education of a girl child by the Union government would be Rs. 959. This is far less than the out-of-pocket expenses incurred by an average parent in providing elementary education at Rs.1163 and secondary/higher secondary education at Rs.2391 for girls in the country (NSS th 64 Round). The situation could not have been more alarming.

Another significant area is employment. In recent years the most significant initiative has been the introduction of the Mahatma Gandhi National Rural Employment Guarantee Act (MGNREGA) which entitles each rural household 100 days of guaranteed wage employment.

The Act stipulates that 'priority shall be given to women in such a way that at least one-third of the beneficiaries shall be women who have registered for work under the Act'. Thus from a gender perspective, the scheme holds great promise for protecting women's access through proactive inclusion especially in the context of larger economic dependence of women on men. However, various studies conducted to evaluate the implementation of the scheme from a gender lens paint a rather bleak picture. 
Almost all major government programmes such as Sarva Shiksha Abhiyan, National Rural Health Mission and ICDS rely on unpaid and underpaid labour of women. Women work either as volunteers or are paid a meagre salary (Ghosh, 2009). For instance, in the case of ICDS, the Anganwadi workers and helpers are extremely overburdened, but are not even paid the minimum wages. Similar is the case with Accredited Social Health Activist (ASHA), Auxiliary Nurse Midwives (ANMs) and para teachers who are the frontline service providers for schemes related to education and health. Lastly, with respect to maternal health, the government has taken a few significant initiatives. Among these is the Janani Surakasha Yojana (JSY) which seeks to promote institutional deliveries. However, as pointed out by many women's rights activists, the scope of the interventions under JSY is extremely narrow and limited. They argue that despite the thrust on institutional delivery, most Primary Health Centres (PHCs), Community Health Centres (CHCs) and district hospitals lack even the basic infrastructure and human resources. The major Gender related concerns on MGNREGA are:

(a) Excessive focus on labour intensive works often results in significantly lower earnings for women, (b) Denial of job cards to single women, and (c) Lack of worksite facilities especially crèche facility.

\section{Summary And Conclusion}

India shares with other ex-colonies around the world a research tradition questioning the role of the nation as well as entities with global spheres of influence such as colonial and neocolonial states and multinational corporations. It shares with other countries that have many cultures, religions, and significant indigenous populations the simultaneous existence of alternative understandings of gender: This is reflected in the research. The rise of right-wing fundamentalist organizations has been a global phenomenon through the past few decades of the twentieth century. The feminist, womanist, and social justice research on gender in India is, as in the United States, in political conflict with those with an ultra-rightist agenda. A difference is that while questions about the nature of citizenship and multiculturalism are beginning to frame debates about nations in societies such as the United States, this type of research has longer roots in India. Given the multicultural, economically diverse nature of the country, and the variety of contexts within which gender hierarchies are understood, studied, and challenged, it is likely that the research will remain.

\section{Efficient utilization of funds}

The Ministry of Women and Child Development suffers from under-utilization of funds therefore there is need of increasing public awareness of all women specific schemes by effective communication through community radio/ FM channels, electronic and print media in all regional languages. Leaflets on each scheme with a simple format explaining the procedure should be provided to be distributed at the Gram Sabha, the District councils and the Public Relations Department of State Governments. A Central Help Desk for women must be established at Shastri Bhavan, Delhi to look into redressals' in cases of apathy by the state government.

\section{State government participation}

In Centrally Sponsored Schemes, where the Centre gives $50 \%$ or $60 \%$ or $75 \%$ share of the funds and the state government is expected to give $25 \%$, the ministry should pressurize the state government to contribute its share of fund, land, building etc. So that schemes can be implemented.

\section{Reduce processing days}

Political decentralization must be supported by financial decentralization. Once the fund is parked in the ministry, schemes and programmes must be immediately clocked so that fund flow is made available to the local self government bodies within a month. Processing of proposals by women's groups, SHGs and elected women representatives must be done within 15 days of submission.

\section{Checks and balances that need to be in place make gender budgeting more effective}

a. Provide for people's participation in both budget making and its utilization to make expenditure process transparent.

b. Women's groups and citizen's organizations should use Right to Information to deal with bureaucratic apathy/antipathy, bungling, corruption and leakages.

c. The Ministry must clearly spell out various components of funds, functions and functionaries in a particular scheme/programme.

d. The government must build capacity of elected women representative with regards to budget making, proposal writing and proposal defending, maintenance of accounts, and RTI.

e. Evaluation Studies need to be commissioned to highlight the gap between plan outlay and outcome, local and global implications of pro-poor and pro-women budgeting, alternative macro scenarios emerging out of alternative budgets and interlinkages between gender-sensitive budgeting and women's empowerment. 
f. Government departments must be sensitized about the visibility of women in statistics and indicators by holding conceptually and technically sound training workshops by gender economists.

\section{References}

[1]. Rajesh, Gender Justice in Advertisements: Study of Indian Commercials, International Research Journal of Social Sciences, January 2014, Vol. 3(1), 17-20.

[2]. Vijaya Mahajan, Women Empowerment and Social Justice: A Socialist Feminist Social Work Approach, 2012 International Conference on Humanity, History and Society IPEDR vol.34 (2012) (C) (2012) IACSIT Press, Singapore.

[3]. Carr M, Chen M, Jhabwala R, Speaking out, Women's economic Empowerment in South asia, Vistaar Publications, New Delhi, 1998, p-12.

[4]. Ganguli Mukherjee, G., Majhi A.K., Jana, S.K. (2000), .Evaluation of 1120 Women Seeking Sterilisation Reversal ., Journal of the Indian Medical Association (JIMA), Volume-98, Number 4, Calcutta, April.

[5]. Gopalan, S. and Shiva, M (2000), National Profile on Women, Health and Development- Country Profile- India, Voluntary Health Association of India and World Health Organisation.

[6]. Gupte, M. and Shatrughana, V. (1988), Shrama Shakti Report, GOI.

[7]. Jain, D. (1996), "Valuing Women's Work: Time as a Measure", Economic and Political Weekly, vol. XXXI, no 43, October 26,WS46-WS 57.

[8]. Kapur Mehta, A. (1996), "Recasting Indices for Developing Countries- A Gender Empowerment Measure", Economic and Political Weekly, October 26, WS 80-WS86.

[9]. K. Seeta Prabhu, P.C. Sarkar and A. Radha (1996), "Gender Related Development Index for Indian States- Methodological Issues", Economic and Political Weekly, Vol. XXXI, No.43, October, 26, pp. WS 72-WS79

[10]. Kaushik, S. (2002), .Economic Empowerment of Women- Some Issues., Urdhava Mula, Mumbai, Vol.1, No.1, pp.16-29.

[11]. Kramarae, C. and Spender, D. (2000), Routledge International Encyclopedia of Women-Global Women.s Issues and Knowledge, Vol I, II Routledge, New York.

[12]. Krishnaraj, M. (ed) (1991), "Women in the Data Systems", Research Centre for Women.s Studies, SNDT Women.s University, Mumbai.

[13]. Patel, V. (2002), .Gendering the Budget at State and National Level and Gender Audit of the Union Budget- A critical Approach., Urdhva Mula, Mumbai, Vol. 1, No. 1, pp.30-57.

[14]. Sau, S. (2001), Trend of Panchayat Development Finance: A Study of Six Gram Panchayats in Midnapore District of West Bengal., Department of Economics with Rural Development, Vidyasagar University, Midnapur, West Bengal.

[15]. Patel, V. (2009) http://www.gender-budgets.org/content/ view/292/156/ United Nations Development Fund for Women (UNIFEM) and The Commonwealth Secretariat. 